\title{
Neutrophil-lymphocyte ratio and right ventricular dysfunction
}

We have read the article "Neutrophil/lymphocyte ratio is associated with right ventricular dysfunction in patients with acute inferior ST-elevation myocardial infarction" by Yaylak et al. [1]. They aimed to prove the relationship between the neutrophil/lymphocyte ratio (NLR) and right ventricular (RV) dysfunction in patients with inferior ST elevation myocardial infarction (STEMI) who underwent primary percutaneous coronary intervention (pPCI). They concluded that NLR was an independent predictor of RV dysfunction in patients with inferior STEMI having undergone pPCI.

Based on this particular study, some important issues should be emphasized. Firstly, inferior STEMI is related to short-term morbidity and mortality, especially in patients with coexisting $\mathrm{RV}$ involvement. In the present study, Yaylak et al. [1] clamied that the groups were divided into two groups according to tricuspid annular plane systolic excursion levels. However, RV function is measured by many methods [2]. Secondly, because patients with STEMI have increased stress, which can change the subgroups' leukocyte levels, NLR may change from time to time. Also, the features of the tube which contains blood specimens may alter complete blood count (CBC) parameters. Therefore, $\mathrm{CBC}$ parameters may be altered by measurement time and features of the tube [3]. Furthermore, although NLR is a simple, cheap, widely used inflammatory marker, major confounding factors should be considered [4]. One of the confounding factors would be certain cancers inflammatory disease may alter NLR levels $[5,6]$. Another factor, NLR, is significantly changed by many conditions, such as dehydration, overhydration, diluted blood specimens, or in-vitro blood specimen handling [7]. Also, the relation between widely accepted inflammatory markers, particularly C-reactive protein and NLR levels, should have been assessed; the recent study might have provided unique information. Finally, it might have investigated the relation between NLR and widely used inflammatory markers, e.g. red cell distribution width [8].
As a conclusion, the role of inflammatory markers in cardiovascular disease (CVD) has been reviewed extensively and a significant relationship between NLR and CVD has been established $[6,9,10]$. NLR is an independent predictor of RV dysfunction in patients with inferior STEMI undergoing pPCI as presented in the current study, however, when assessing the relation NLR and RV function, the clinicians should consider the abovementioned factors.

\section{Conflict of interest: None declared}

\section{References}

1. Yaylak B, Ede H, Baysal E et al. Neutrophil/lymphocyte ratio is associated with right ventricular dysfunction in patients with acute inferior ST-segment elevation myocardial infarction. Cardiol J, 2016; 23: 100-106. doi: 10.5603/CJ.a2016.0061.

2. Demirkol S, Unlü M, Arslan $Z$ et al. Assessment of right ventricular systolic function with $\mathrm{dP} / \mathrm{dt}$ in healthy subjects: an observational study. Anadolu Kardiyol Derg, 2013; 13: 103-107.

3. Celık T, Balta S, Demır M et al. Predictive value of admission red cell distribution width-platelet ratio for no-reflow phenomenon in acute ST segment elevation myocardial infarction undergoing primary percutaneous coronary intervention. Cardiol J, 2016; 23: 84-92.

4. Balta S, Demirkol S, Unlu M, Ozturk C, Arslan Z, Celık T. Neutrophil-lymphocyte ratio: Can clinicians really trust it as an inflammatory indicator? Cardiol J, 2015; 22: 475.

5. Balta S, Demirkol S, Unlu M, Arslan Z, Celik T. Neutrophil to lymphocyte ratio may be predict of mortality in all conditions. $\mathrm{Br}$ J Cancer, 2013; 109: 3125-3126.

6. Ozturk C, Balta S, Balta I, Celik T. Neutrophil-lymphocyte ratio in behçet disease. Angiology, 2015; 66: 695.

7. Balta S, Celik T, Mikhailidis DP et al. The relation between atherosclerosis and the neutrophil-lymphocyte ratio. Clin Appl Thromb Hemost, 2016; 22: 405-411.

8. Demirkol S, Balta S, Cakar M, Unlu M, Arslan Z, Kucuk U. Red cell distribution width: A novel infl ammatory marker in clinical practice. Cardiol J, 2013; 20: 209.

9. Balta S, Ozturk C, Yildirim AO, Aparci M, Demir M, Celik T. The relation between neutrophil-lymphocyte ratio and hypertension. Am J Hypertens, 2015; 28: 1386.

10. Balta S, Demirkol S, Aparcı M, Celik T, Ozturk C. The neutrophil lymphocyte ratio in coronary heart disease. Int J Cardiol, 2014; 176: 267.

Sevket Balta, Cengiz Ozturk, Ali Osman Yıldırım, Sıddık Erdogan, Turgay Celık

Department of Cardiology, Gulhane Medical Faculty, Gulhane School of Medicine, Tevfik Saglam St., 06018 Etlik-Ankara, Turkey tel: +90-312-3044281, fax: +90-312-3044250

e-mail:drsevketb@gmail.com;sevketb@gata.edu.tr 